\title{
Materials Education Council Becomes First MRS Affiliated Organization
}

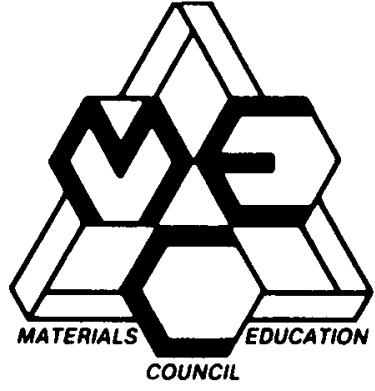

MRS President Bob Chang has announced that the Materials Education Council has been accepted as the first member of the new MRS Affiliated Organization Program. The MRS Affiliated Organization program was established this summer to initiate and recognize cooperative interactions with other organizations concerned with materials research (see the August 1989 MRS BULLETIN, p. 52).

The Materials Education Council and MRS already have a long history of cooperative innovative activities. This is perhaps not surprising since several figures prominent in founding MRS also helped to establish this educational effort. Harry Gatos, the first president of MRS, and Robert A. Huggins, currently an MRS councillor, were involved in beginning an experimental film project; and Rustum Roy, a former MRS councillor, was the director of several key projects of the Council.

The Materials Education Council was founded as an advisory committee, first to the National Materials Science Film Project (1970) and then to its successor, the Educational Modules for Materials Science and Engineering Project-both supported by the National Science Foundation (NSF). The Council has since evolved into the international materials science and engineer- ing community's self-help program in preparing and distributing educational materials.

The initial and continuing rationale for the Council's development was the recognition that producing new instructional materials in forms other than textbooks was a key to improving content, modernizing curriculum, and integrating the many fields of materials. From this base the concept of modules was developed. The modules, pedagogically sound study packages on various materials topics, utilize a variety of media-print, movies, television, and computer software. They are generated from various sources, inclưding module preparation workshops, individual submissions, and review papers presented at scientific meetings such as those characterized by the Symposium $X$ series (Frontiers of Materials Science) at MRS meetings. Future plans of the Council include PC software for materials science teaching and technology transfer via teleconferencing.

Although initial NSF support for science education waned considerably during the Reagan administration, funds from NATO and other European sources sustained the Materials Education Council and its Western European links. Now the Council is a self-supporting, not-for-profit organization whose income is generated from sales of the Joumal of Materials Education and topical "clusters" or sets of modules. The four main sets address crystallography, polymer laboratory experiments, wood as a material (a complete series), and cement science. Altogether, nearly 10,000 of the modules are sold every year. The Joumal of Materials Education, now in its eleventh year of publication, is an innovative journal-textbook hybrid conferring unlimited copying rights to institutional subscribers. Faculty and students simply copy what they need, selecting a "best set" of modules on a particular topic from back issues. The Journal is now translated into Japanese for distribution in Japan.

Cooperative efforts of the Materials Education Council and MRS have recently been extended to video projects. In addition to videotaping the proceedings of Symposium $X$ at both the MRS Spring and Fall Meetings, oral histories of the founding of interdisciplinary materials research and the discovery of high $T_{c}$ oxide superconductors have been recorded. At the 1989 MRS Fall Meeting in Boston in November, the Materials Education Council and MRS will co-produce a live national satellite broadcast of some of the most exciting advances in the materials field. The National Technological University (NTU) and PBS Adult Learning Satellite Service will broadcast the presentation to industrial and academic sites nationwide, with opportunities for teleconference questions and answers. This format, a forerunner of professional meetings of the future, is the type of mutually beneficial cooperation that both organizations anticipate will continue in the future.

Members of the Materials Education Council now include: Rustum Roy (Pennsylvania State University), Witold Brostow (University of North Texas), Stephen Carr (Northwestern University), Robert Davis (North Carolina State University), Craig Hartley (University of Alabama-Birmingham), Bruce Knox (Pennsylvania State University), L.H. Van Vlack (University of Michigan), Charles Wert (University of Illinois), W. David Kingery (University of Arizona), John Baglin (IBM), James Jacobs (Norfolk State University), and Robert Berrettini (Pennsylvania State University).

MIRTS

\section{MRS BULLETIN}

\section{Covers the Signficiant Developments and Trends in Materials Research}

Bring the significant developments at your institution to the attention of your colleagues around the world. Ask your public relations department to send information for inclusion in the BULLETIN to:

Editor, MRS BULLETIN

9800 McKnight Road

Pittsburgh, PA 15237

Telephone (412) 367-3036

Fax (412) 367-4373 


\section{NEW IN MATERIALS RESEARCH}

FROM

\section{CHAPMAN AND HALL}

\section{Glass and Glass Ceramics}

\section{Edited by M.H. Lewis}

Lewis provides a timely treatment of this important new class of materials by the leading international authorities in the field.

$416 \mathrm{pp}$

$\$ 82.50 /$ cloth

\section{Adhesion and Adhesives}

Science and Technology

\section{J. Kinloch}

"A wonderfully readable book!...Very highly recommended!"

$570 \mathrm{pp} \quad$-Adhesives and Sealants Newsletter
$\$ 85.00 /$ cloth

\section{Polymer Microscopy}

\section{Linda Sawyer}

"This high quality, beautifully produced book is a goldmine of information for the microscopist."

$303 \mathrm{pp}$, photographs -The Microscoper $\$ 115.00 /$ cloth

\section{Polymer Processing}

\section{D.H. Morton-Jones}

Polymer Processing presents an in-depth account of the processing of polymer materials, from the nature and origins of polymers to finished products.
$300 \mathrm{pp}$
$\$ 69.50 /$ cloth
$\$ 29.95 /$ paper

Forthcoming!

\section{Electroceramics}

\section{J. Herbert and A. Moulson}

Herbert and Moulson give us the most complete and upto-date guide to electroceramics yet available.

Electroceramics summarizes the considerable advances made in the last fifty years in solid state theory and its applications to electroceramics.

$500 \mathrm{pp}$, illustrations

$\$ 85.00 /$ cloth

\section{Polymer Characterization}

Physical Techniques

\section{J.R. White and D. Campbell}

White and Campbell describe the key physical techniques used to determine the characteristics that lead to the vast range of properties associated with polymers and polymer-based materials.

$380 \mathrm{pp} \quad \$ 87.50 /$ cloth $\$ 36.00 /$ paper

\section{Second Edition}

\section{Chemistry of Glasses}

\section{Amal Paul}

"...will be regarded as an important addition to all glass and ceramic libraries throughout the world."

$340 \mathrm{pp}$, illustrations

$\$ 75.00 /$ cloth

\section{Choice}

\section{Conductive Polymers and Plastics}

\section{Edited by James A. Margolis}

Covers the state-of-the-art techniques for producing both conventional conductive plastics and the newer intrinsically conductive plastics (ICPs) $320 \mathrm{pp}$

$\$ 115.00 /$ cloth
Chapman and Hall 29 West 35th Street

New York, NY 10001

\section{Publishers of:}

The Journal of Materials Science and The Journal of Optical and Quantum Mechanics 